\title{
The Philippine Islands: a vital crossroads during the first globalization period
}

\author{
Carlos Martínez Shaw and Marina Alfonso Mola \\ Department of Modern History, Facultad de Humanidades, C/ Senda del Rey, 7, Madrid, 28040, UNED \\ e-mail:cmshaw@geo.uned.es,malfonso@geo.uned.es
}

Submitted: 10 April 2014. Accepted: 15 May 2014

\begin{abstract}
The first globalization is a concept which should be interpreted as the period during which a system of exchanges of every kind (human, economic, cultural) was established between the different continents, unknown to each other until the last decade of the $15^{\text {th }}$ century. After being conquered by Spain in 1565 , the Philippine Islands represented a vital crossroads in this process. Firstly, the islands acted as a major distributor of Mexican silver in the Pacific sphere. Secondly, they were Spain's launching pad for access to neighbouring kingdoms (China, Japan, the countries of Southeast Asia, the Spice Islands), with which it was connected by means of trade, missionary activities, diplomacy and sometimes war. News, learning and exotic products were taken from the islands to Mexico and other parts of Spanish America. Lastly, the Philippine Islands were connected directly to the mother country following the opening of the Cape of Good Hope route by various ships, dispatched first by the Navy, then by private trading companies and lastly, by the Royal Company of the Philippines. The Seville (or Cádiz)-Veracruz-Mexico City-AcapulcoManila axis, with movement in both directions, served as a permanent route for the exchange of precious metals and exotic products.
\end{abstract}

KEYWORDS: Spain; America; Asia; $16^{\text {th }}-18^{\text {th }}$ Centuries; Silver; Trade Relations; Cultural Exchange

Citation / Cómo citar este artículo: Martínez Shaw, Carlos and Alfonso Mola, Marina (2014). "The Philippine Islands: a vital crossroads during the first globalization period". Culture \& History Digital Journal, 3(1): e004. doi: http://dx.doi.org/10.3989/chdj.2014.004

RESUMEN: Las Islas Filipinas: un cruce vital en la era de la primera globalización.- La primera globalización es una noción que debe interpretarse como el periodo en que se establece un sistema de intercambios de toda índole (humanos, económicos, culturales) entre los distintos continentes que hasta la última década del siglo XV se desconocían mutuamente. Las Islas Filipinas, tras su conquista por España en 1565, constituyeron una encrucijada vital para este proceso. Primero, las islas jugaron el papel de gran distribuidor de la plata mexicana en el espacio del Pacífico. Segundo, fueron la plataforma española para alcanzar los reinos vecinos (China, Japón, los países del Sudeste de Asia, las Islas de las Especias), con los que se relacionaron a través del comercio, la acción misional, la diplomacia y, a veces, la guerra, y desde donde se transfirieron noticias, conocimientos y productos exóticos a México y otras áreas de la América hispana. Finalmente, las Islas Filipinas se comunicaron directamente con la metrópoli tras la apertura de la ruta del Cabo de Buena Esperanza y a través del envío de diversos buques de la Armada primero, de algunas sociedades mercantiles privadas después y de la Real Compañía de Filipinas finalmente. Así, el eje Sevilla (o Cádiz)-VeracruzMéxico-Acapulco-Manila, vigente en ambas direcciones, sirvió como vía permanente para los intercambios de metales preciosos y productos exóticos, así como para las transferencias culturales de toda índole, entre España, América y Asia, a lo largo de los tiempos modernos.

PALABRAS CLAVE: España; América; Asia; siglos XVI-XVIII; Plata; Relaciones comerciales; intercambios culturales

Copyright: (C) 2014 CSIC. This is an open-access article distributed under the terms of the Creative Commons AttributionNon Commercial (by-nc) Spain 3.0 License. 
The first globalization is a concept which should be interpreted as the period during which a system of exchanges of every kind (human, economic, cultural) was established between the different continents, which until the last decade of the $15^{\text {th }}$ century had been unknown to each other. The key dates in this historical context span 30 years: the discovery of America by Christopher Columbus (1492), Vasco de Gama's arrival in India (1498), the discovery of the South Sea by Vasco Núñez de Balboa (1513) and the circumnavigation of the world by the fleet which set off under the command of Ferdinand Magellan and completed its voyage under Juan Sebastián Elcano (1522). The first of these events made it possible to forge a connection between Europe and an unknown continent, which the Europeans explored and colonized over the course of the $16^{\text {th }}$ century and beyond. The second marked the arrival point for a lengthy exploration, first of the western coast of Africa and then its eastern coast, before finally landing in India. This opened up the possibility of continuing the voyage until they reached the lands of the Asian Far East: Malaysia, China and Japan. The third event presented the possibility of crossing America and from its western coast, embarking on journeys of exploration both northward and southward. It also offered the option of venturing across a vast ocean, a voyage that would reveal the existence of a far-flung world of islands and would also ultimately lead to the Asian Far East from the opposite side. The voyage around the world established interconnections among all of the previous pieces: it led to the Americas via the Atlantic Ocean, to the Pacific Ocean via the Strait of Magellan, to East and South Asia, across the Indian Ocean to Africa and back around Africa, returning to Europe, the starting point. And so the most immediate consequences of the explorations undertaken during this thirty-year period would be the creation of a network of intercontinental exchanges, the discovery of the existence of many worlds, the paradoxical emergence of a single world for the first time and the possibility, also for the first time, of conceiving of a universal history.

The Portuguese route placed Lisbon at the European end of an axis of communications which ran along the African coast, reached India and continued on to its Asian terminus, defined by the Chinese coasts and the arc of islands extending from Japan to Indonesia, with the Philippine Islands at the centre. The Spanish route positioned Seville (and later Cádiz) at the European end of another axis which linked Spain with both Veracruz and the Atlantic ports of Panama. From there, it continued across the American continent either via the Isthmus of Panama to the port of El Callao in Peru, or along the old route of the viceroys to Mexico City and then along the "Asia Route" to the port of Acapulco. From there it crossed the Pacific Ocean, the "Spanish Lake", to the Philippine Islands, where it converged with the Portuguese route. Thus, in geographic terms, the Philippine Islands became the terminus of the two major routes of the first globalization period, with one other distinctive feature: after 1565, the Hispanic monarchy held sovereignty over the archipelago.

\section{THE SPANISH IN THE PHILIPPINES}

Beginning in 1503, the route which linked the terminus at Seville with the American ports on the Atlantic was supervised by the House of Trade (Casa de la Contratación). This institution would run the system of trade known as the Indies Route (Carrera de Indias) for three centuries. The system encompassed a network of several American ports. The most important were Veracruz, which supplied the Viceroyalty of Mexico, or New Spain; those that supplied the Viceroyalty of Peru: Nombre de Dios (later replaced by Portobelo) and Cartagena de Indias on the Atlantic, as well as Panama and El Callao on the Pacific, which were reached via the isthmus; and lastly Havana, on the island of Cuba, where the two fleets - one to New Spain and one to Tierra Firme and Peru - converged en route back to Seville (and from 1717, to Cádiz) (García-Baquero González, 1992).

Until well into the $16^{\text {th }}$ century, goods shipped from Seville reached Mexico City (where the Merchant Guild (Consulado) founded in the city organized their redistribution to every corner of the viceroyalty) and Lima (with that city's Merchant Guild redistributing the goods to the entire viceroyalty). However, the 1513 discovery of the South Sea marked the beginning of a series of explorations of the Pacific Ocean, in pursuit of various aims. The first of these was access to the Moluccas, the legendary Spice Islands, which would soon become the private preserve of Portuguese trade after Spain relinquished any possible claim to the islands (Treaty of Zaragoza, 1529). The second was a permanent presence on the Philippine Islands, which time and again had been situated on the route of expeditions to the Moluccas and which could serve as a solid base between the Americas and Asia. This was achieved in 1565. The third and final aim (of less interest to us here), was the attempt to discover the mythical Terra Australis, the southern land which the imagined models of ancient geography believed must balance out the continental mass of the Northern Hemisphere (Martínez Shaw, 1998, 2001; Landín Carrasco, 1991; Spate, 2006).

Having reached the Philippine Islands in February 1565, Miguel López de Legazpi took possession of the successive islands in the archipelago he visited: Ibabao, Samar, Leyte, Limasawa, Camiguin, Bohol, Mindanao, Siquijor, Negros and, finally, Cebu, where he founded the first Spanish settlement, Villa de San Miguel. From there, he continued on to the island of Panay, where he received the assistance sent to him by Martín Enríquez de Almansa, the viceroy of New Spain: three ships with a military detachment under the command of Juan de Isla. They also carried the eagerly awaited royal deeds for the expedition leader, granting him the title of adelantado to conquer and govern the "Islands of the Thieves" (the Mariana Islands), with the power to found cities and distribute sections of land known as encomiendas. It was now time to occupy the islands of Panay, Masbate and Mindoro (where he rescued the Chinese 
slaves with the intention of establishing friendly relations, an action which produced positive results). From there, he went on to the island of Luzon, which from that time forward would constitute the centre of Spanish control over the archipelago (Cabrero, 2004: 229-462).

Once in Luzon, following the exploratory mission led by Martín de Goiti, Legazpi spend two days in Cavite before preparing to disembark in the village called Maynila. Taking advantage of dissension among the three Muslim rulers (Sulayman, Matanda and Lakandula), he obtained concessions for land in the area of the Pasig River, around a magnificent natural port. He officially founded the city of Manila there on July 24th, 1571 , enacting the by-laws of its council and making it the capital of the Philippines. He then immediately undertook the conquest of the rest of the island. This conquest was extended to other island groups by his successors to the governorship. The only areas that would remain outside their jurisdiction were part of the territory of Mindanao and the most distant archipelago, Jolo or Sulu, which would continue to be an independent territory in the hands of various Muslim sovereigns (Alonso Álvarez, 2004).

The death of Legazpi (in August 1572) did not halt the process of regulating the institutions of the Philippine Islands, which were raised to the rank of captaincy general, with a sovereign government and their own audiencia (royal court). As stated in the deed, the final jurisdiction encompassed "the island of Luzon, all of the other Philippine Islands, the China archipelago and the mainland, that which has been discovered and is yet to be discovered". However, in reality, the Spanish held actual control first over the island of Luzon and the Visayas island group (Panay, Cebu, Leyte, Samar). Other islands were progressively added, along with part of the island of Mindanao, up to the enclave of Zamboanga. This is where the socalled Moorish frontier began, the territory controlled by the Muslim sultans and datos, both on the island itself and in the Sulu Archipelago. Lastly, the Mariana Islands fell under the domain of the Philippines, although for a long period of time, Spanish sovereignty was nominal, despite the island of Guam serving as port of call for the Manila Galleon (Phelan, 1967; Cushner, 1971; Cabrero, 2000).

\section{MEXICAN SILVER IN THE FAR EAST}

Thus, the Philippine capital of Manila became on one hand, the setting-off point for making a number of contacts with neighbouring countries. These would be alternatively commercial, missionary, diplomatic and military, and would increase significantly following the union of the Spanish and Portuguese crowns in 1580 (Valladares, 2002; Martínez Shaw \& Martínez Torres, 2014). On the other hand, Manila was also the terminus of the great trans-Pacific trade route known as the Manila Galleon or "Nao de China". This route linked the Philippine Islands and the Viceroyalty of New Spain for more than two centuries, from the final third of the $16^{\text {th }}$ century to the second decade of the $19^{\text {th }}$ century (Schurz, 1992; Yuste López, 1984; Alfonso Mola \& Martínez Shaw, 2003).

While the route's two termini were Manila in the Philippines and Acapulco in Mexico, the trade route had to extend further east and west at either end. In the direction of the Asian continent, the Philippine port benefitted from a pre-existing flow of trade which connected the archipelago with its neighbouring territories. Conversely, its connection with the American continent made it possible for the first time to incorporate this regional traffic into the wider scope of international maritime trade, within a new planet-wide system. In the opposite direction, part of the merchandise brought to the Mexican coast was distributed within the Viceroyalty of New Spain or sent on to other parts of Spanish America. However, another part travelled the route to Veracruz on the Atlantic coast to be shipped to the mother country via the Indies Route, whose ports in Seville, and later Cádiz, received products from the Far East via this single route (Bernal, 2004). Traffic between the Philippines and Mexico began in 1565 with the sailing of the galleon San Pedro, captained by Felipe de Salcedo, with Augustinian friar Andrés de Urdaneta as its chief pilot and a crew of two hundred men. It made port in Acapulco, which from then on would serve as the American end of the Manila Galleon route. However, during the final years of the $16^{\text {th }}$ century, there was an alternative route, with ships sailing from the Philippine capital to the Peruvian port of El Callao, the Nicaraguan port of Realejo and the port at Huatulco on the Mexican coast, just as Peruvian ships travelled to Acapulco to stock up on the most sought-after Chinese products (Cárdenas de la Peña, 1965; Truchuelo García, 2009: 479-561). However, the Spanish crown soon began to combat Peruvian trade connections with the Far East, in response to complaints from Spanish and Mexican "fleet members". As a result, in 1591, traffic between Guatemala, Tierra Firme and Peru was banned, as well as traffic from any port apart from Acapulco "with China and the Philippines" (Schurz, 1992: 312-313; Borah, 1954; Iwasaki Cauti, 1992: 21-54).

In any event, as was typical, this traffic came to be regulated beginning in 1593, the year in which a timetable of two annual sailings was established (which merchant interests would soon reduce to a single sailing). Merchandise valued at 300,000 pesos was loaded in Manila, with double that amount in pesos fuertes being loaded in Acapulco. These amounts would be increased over the years by successive decrees, officially updating the size of the transactions. The galleon departed from Cavite-Manila's neighbouring port at the mouth of the Pasig - in the month of July, in order to take advantage of the summer monsoon. When it reached the latitude of Japan, it followed the Kuroshio Current to the California coast, landing at Acapulco in December (normally between Christmas and New Year), when it was unloaded. The annual fair was then held - with large 


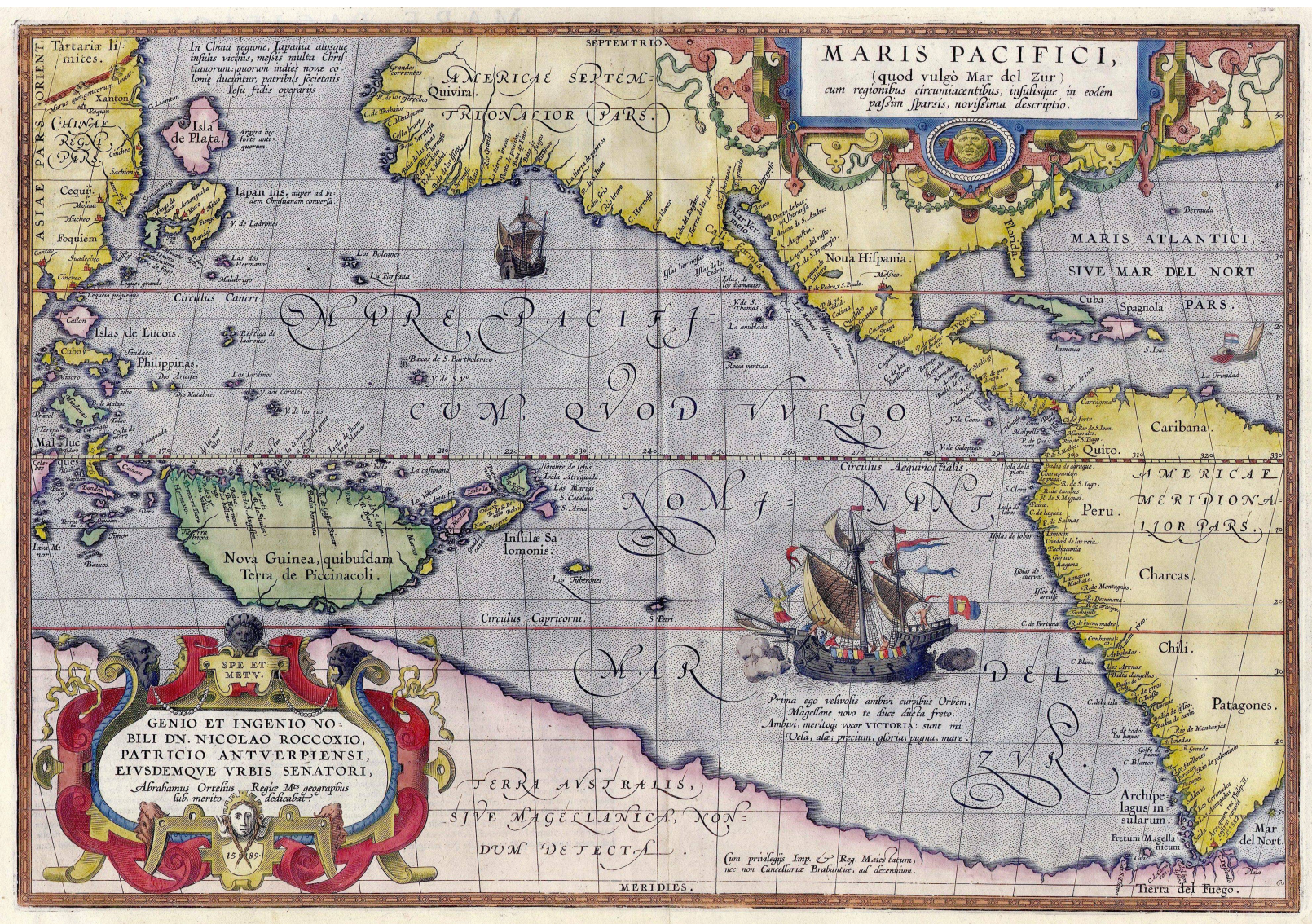

Abraham Ortelius, Maris Pacifici, 1589.

This map was published in the "Theatrum Orbis Terrarum. It was not only the first printed map of the Pacific, but it also showed the Americas for the first time.

numbers of merchants from Mexico City, as well as Puebla, Oaxaca and neighbouring towns - under the supervision of the mayor and the castellan of Fort San Diego, built in 1617. In the month of March, or April at the latest, the galleon departed from Acapulco and after stopping at the Mariana Islands, it reached Manila in July, in time to see its successor on the route set off (Alonso Álvarez, 2009; 2013; Yuste, 2013).

Trade in Manila was primarily controlled by Chinese merchants (commonly known as Sangleyes), whose junks brought foodstuffs to the Philippine capital (wheat and barley, sugar and fresh and dried fruit, especially grapes and oranges), but especially manufactured goods from throughout the Eastern world. Deals were made in an open market known as the Parián de los Sangleyes, where Spanish merchants who were permanent residents of the Philippines came to negotiate prices and quotas for goods to be sent to Acapulco. This was conducted by means of a complicated officially regulated system known as the pancada. Over time, trading escaped the control of the pancada, just as Chinese merchants had to withstand competition from English, Moorish, Armenian and Spanish merchants interested in this trade. In any case, just as in Seville with the ships of the Indies
Route, the Galleon was a monopoly of individuals and the ship (or tonnage) had to be divided exclusively amongst Spaniards resident in Manila. They either travelled with the goods they had purchased or entrusted stewards with their care and sale once the ship had reached New Spain. ${ }^{1}$

Trade was essentially based on remittances of silver from Acapulco to Manila, which were exchanged for a number of Asian products, many of them brought over on Chinese sampans. Over the course of the $18^{\text {th }}$ century, these were joined by the ships of European countries that had established themselves in the region. While Spanish silver from Acapulco was primarily sent on to the coasts of China, the holds of the galleons that departed from Manila were filled with Chinese products (mostly silk and porcelain goods). However, they also carried Japanese lacquered goods, furniture and ivory from Portuguese India, cotton textiles from Bengal and spices (pepper and cloves from the Moluccas, cinnamon from Ceylon), as well as certain typical Philippine products, which always accounted for a small percentage of the hold's contents. In the other direction, the cargo of silver (96-99\% of the total) was filled out with certain other products such as cochineal from Oaxaca, soap 
from Puebla and indigo from Guatemala, as well as official shipments, which included Royal Treasury stamped paper and accounts (naipes de cuentas), along with items destined for the Royal Warehouses, for the use of authorities and the missions. The latter included anything from paintings and religious images to wine to be consecrated (Yuste, 1984; 2007).

American silver was therefore the foundation or cornerstone of the Manila Galleon. In Manila, Spanish currency (especially the peso fuerte, the eight-real peso, also commonly known as the piece of eight) was used above all to pay for Asian goods shipped on to Mexico. As a result, a large portion of the pieces of eight ended up in the hands of the Sangleyes, the Chinese merchants who operated out of the Parián de Manila, who in turn acted as intermediaries for the many Chinese junks that travelled to the Philippines. There was another route which brought American silver into the hands of other intermediaries, Portuguese merchants in Macau. When they could not get it directly from Portugal (through trade with Seville or smuggling via Brazil), they obtained it through trade with the Spanish Philippines, which may have been legal or illegal, but was always active. In both cases, the metal might then travel on to other destinations, particularly to India, the countries of Southeast Asia or the Spice Islands. ${ }^{2}$

China attracted Spanish American silver for various reasons related to its economic and financial policy. First of all, during the second half of the $15^{\text {th }}$ century, there was a gradual trend in the Middle Kingdom towards using silver for commercial exchanges. Secondly, this stimulus from the private sector soon carried over to the public sector. As a result, the decentralized treasury of the Ming Dynasty also began demanding silver as payment for taxes. Thus, the Chinese Empire became a vast territory subject to a single-metal standard, silver, over the following centuries. However, as China did not have its own silver deposits, its need for the metal had to be met by other countries, particularly by Japan, East Asia's main producer. In fact, the country was a regular source of supply for the Mings before and after Spanish American silver reached the Far East (Kobata, 1965; Kamiki and Yamamura, 1983; Flynn, 1991). In addition, because it offered European traders the opportunity to profit from the high value of the American metal, the hunger for silver in China helped reinforce this trend, which was also aided by the negative balance of trade between Europe and China. Indeed, the European merchants who operated in the region essentially sought silk goods, as well as porcelain and other high quality, high cost objects, but were hardly able to ship goods from their countries of origin that would arouse the interest of the court or individuals in the Middle Kingdom. In this case, it was European (and Spanish American) eagerness to obtain Chinese luxury goods that acted as the impetus for sending pieces of eight to the silver "pit" of the Far East (Atwell, 1988; Myers and Wang, 2002). Godinho (1963-1965, t. 1: 465) describes Philippine as "bomba de absorción de plata". In fact, American silver was necessary for all transactions in the Asian world. As a result, beginning in the mid- $16^{\text {th }}$ century, its influence gradually spread to the Ottoman Empire, the Safavid Empire and the various states of India. Thus, merchants from the different European companies in the East Indies found themselves with the need to acquire this silver, either in Europe or by offering their commercial services. To this end, the practice of engaging in multiple exchanges in various local markets in Asia developed, according to the formula known as country trade (Reid, 1993: 25-32; Quiason, 1966).

To use a phrase that has become famous, on its voyage from Acapulco to Manila, the Galleon essentially transported "friars and silver". The friars came to evangelize the archipelago and the silver came in the form of luxury items (both religious and domestic), but especially in the form of coins to pay for Chinese goods. As a result, Spanish pesos circulated widely in the Celestial Empire, to such an extent that present-day historian Dennis Flynn has even stated - undoubtedly with some degree of exaggeration - that the decisions of the Spanish sovereigns depended to a great extent on the situation in Ming China. In any event, what is certain is that Spain had a negative balance of trade with the Philippines, which had to be compensated for with silver, especially Mexican silver. This was a precious metal for China, which needed it for both transactions in the private sector and for public treasury operations, but did not have its own deposits. Consequently, as we have already mentioned, it had to turn to Japanese mines or Spanish American remittances from Manila (Flynn and Giráldez, 1996).

Asian products also reached the mother country via Mexico. Indeed, Spain received the same silk pieces, lacquer work and ceramics, some expressly commissioned, such as "Indies Company" china for the use of officials, aristocrats and even the royal house (as evidenced by the splendid china with the coat of arms of Philip V). It also received scientific materials such as books, maps and views of those distant lands, including the 1555 map of China held in the General Archive of the Indies in Seville. And then there were the oriental inspired Mexican products, such as Japanese folding screens manufactured in New Spain, pieces with motherof-pearl inlay, maque lacquer work from Michoacán and ceramics from Puebla with oriental motifs (Alfonso Mola and Martínez Shaw, 2003).

In conclusion, the essential fact is that the trade which took place via Manila, between Spain on the one hand and China and other Asian countries on the other, was based on exporting silver from Spanish American mines. Spanish eight-real pesos (the so-called pieces of eight, also known in the region as Spanish pesos, pesos fuertes, silver pesos and "pillar pesos" because of the pillars on the reverse), as well as the pesos coined in Mexico after independence (known as eagle pesos and soon as Mexican dollars), functioned as official legal tender. This was indicated by stamping them with Chinese characters known as "chop" marks, which can 
be seen on the many pieces preserved in various museums and private collections both inside and outside Spain. Thus, Spanish (Mexican and Peruvian) silver was one of the major catalysts of the first globalization.

\section{THE PHILIPPINE ISLANDS AS A LAUNCHING PAD TO EAST ASIA}

As we have already indicated, for Spain, Manila was not just the terminus of the trade route from Acapulco, it was also a launching pad located between the west coast of the Americas and the east coast of Asia, a springboard to stimulate contacts with neighbouring Asian states and conversely, to begin the colonization of Micronesia. With regard to the latter, the Mariana Islands joined the empire as a result of a mission led by the Jesuits (1668), while the Caroline Islands came into the Spanish orbit following the arrival of Francisco Lezcano from Palau (1686) and also later when the Jesuits settled there (1710). These initiatives laid the foundations for the creation of Spanish Micronesia. These domains were halfway between Mexico and the Philippines, at a point along the extremely long route from Seville to Manila (Galván Guijo, 1998; Hidalgo Nuchera, 1983; Morales and Le Gobien, 2013).

Manila also had to extend itself further in the opposite direction, towards China, Japan and the independent state of Ryukyu (also known as Lewchew), Siam, Cambodia, the various kingdoms of Vietnam, Formosa, Malaysia, Indonesia (especially the Moluccas) and, very tangentially, Korea, Laos and Burma. Contacts took the form of trade, evangelization, diplomacy and war. They began with an early expansion phase initiated by Spanish settlement and ended with withdrawal from the most forward positions occupied at the time of the union with Portugal. They also continued during the $18^{\text {th }}$ century after Spain recovered its imperial initiative. Thus, during the early modern period, there was an entire network of exchanges and information in operation, with its epicentre at the city of Manila: "mistress of many seas, capital of many archipelagos and hub and storehouse of the Orient" (Torre Villar, 1980; "El Elogio de Manila, en Zaragoza", 1990: 24). Manila's westward expansion began with instructions given in 1572 by Martín Enríquez de Almansa, viceroy of New Spain, to captain Juan de Isla. After he entered Manila with his fleet of three ships, he was to embark on one of them with a contingent of men recruited by Miguel López de Legazpi to undertake the exploration of China's coasts. However, the operation was never carried out. It continued with the plan - not only for exploration, but now openly for conquest - laid out by the new governor, Guido de Lavezares (1572-1575), in a letter sent to Philip II in 1574. Significantly, it included the above-mentioned 1555 map preserved in the General Archive of the Indies. Lastly, in that same decade, this desire for conquest would be adopted in a determined fashion by the following governor of the Philippines, Francisco de Sande (1575-1580). He found support for his plans in the first
Spanish embassy to the Middle Kingdom, carried out in 1575 by the Augustinian Martín de Rada. His information would be used as documentation in successive letters sent to Spain in 1576 by the archipelago's top authority, containing such bold proposals as the following: "Regarding China, the job is simple and will not cost much, as Spaniards selected to serve will come at their own expense without payment, and they will pay for freightage and be fortunate." With a fleet capable of carrying between four and six thousand men, "the entire conquest" would be a done thing. However, the Council of the Indies (Consejo de Indias) showed itself to be much more prudent than the imaginative governor. In 1577 , it ordered the suspension of all military intentions and that it should be attempted to have "a good friendship with the Chinese". This did not prevent the idea of conquest from entering the minds of certain other figures, including governor Diego Ronquillo (1580-1583) and Father Alonso Sánchez. Even at the late date of 1584 , it was still possible to discuss such an ambitious plan as that proposed by the Bishop of Malacca, Joâo Ribeio Gaio. He devised a proposal for a joint Portuguese-Spanish expedition to conquer the Sultanate of Aceh (on the island of Sumatra), the city of Patani, the kingdom of Siam and the city of Canton in China from bases in Goa and Manila (González Mendoza, 1990; Ollé, 2000a, 2002).

Apart from these military plans, evangelization was another of the paths pursued as a way to approach China. However, in this case, the Christianizing aims of the Spanish missionaries came up against the rivalry with Portugal. This led Philip II to ban such initiatives in 1589 in order to avoid a conflict in the heart of his own empire in the Far East. Nonetheless, experts have pointed to the numerous successions of attempts (before and after the ban) as the fruit of a true "obsession with evangelizing China", the same obsession that had led St Francis Xavier to his death off the Guangdong coast, on Shangchuan Island, in 1552. In 1570, the Augustinians who had arrived with Legazpi sent Philip II a letter requesting that they be included in a future embassy charged with establishing trade relations with the Chinese Empire. A short time later, in 1572 (the year in which the Augustinians had called the area of their mission in the Far East the "province of China", rather than the Philippines, which would have been the logical name), another two Augustinian friars devised a strategy to gain access to the Celestial Empire by means of the roundabout process of selling themselves to Chinese merchants as slaves. The plan was overridden by Legazpi. Next came the mission of Martín de Rada (accompanied by three other Spaniards), although he was forced to return to Manila without achieving his aim of bringing the Christian faith to that land. He would however leave an account of the undertaking that would become part of the work written by fellow Augustinian Juan González de Mendoza, his famous Historia de las cosas más notables, ritos y costumbres del gran reino de la China (History of the Great and Mighty Kingdom 
of China and the Situation Thereof), published in Rome in 1585. The Augustinians again landed in China in 1586 , in the city of Canton, where they remained until 1594, when they became convinced of the impossibility of gaining access to the inland Celestial Empire. In 1587, it was the turn of the Dominicans. They founded a monastery in Macau before being expelled by order of the Portuguese viceroy and sent to Goa, where they were repatriated to Spain. The Augustinians made other attempts, with some successes, unfortunately always fleeting. These included their 1590 settlement on the Fujian coast (from where they were forced to return to Manila, accused of espionage), Macau in 1609, Canton in 1619 and Formosa in 1626. It was not until well into the $17^{\text {th }}$ century that the Spanish friars saw their dream realized, with official authorization to establish missions being granted to the Franciscans in 1632, the Dominicans in 1633, the Manila Jesuits in 1665 and the Augustinians (the first to make the attempt and the last to succeed) in 1680 . However, the true protagonists of the evangelization of China were always the Jesuits from Goa, who, beginning in 1582, would set up their many missions along the route from Macau to Peking (Martínez Shaw and Alfonso Mola, 2007).

The Spanish presence in territories situated around the Philippines intensified beginning in the 1580 s as a result of the union of the crowns of Spain and Portugal. Between 1580 and 1640, this made closer collaboration possible between the two empires in the Far East. And so Spanish Franciscan Martín Ignacio de Loyola was able to circle the world between 1581 and 1584, stopping almost exclusively in Spanish and Portuguese territories: Seville, the Canary Islands, Veracruz, Mexico City, Acapulco, the Mariana Islands, Manila, Macau, Malacca, Ceylon, Kochi, Goa, the Maldives, Madagascar, Santa Elena and the Azores, before ending his journey in Lisbon. In contrast, Portuguese Pedro Teixeira would travel in the opposite direction. He was able to complete his journey around the world via the Spanish-Portuguese empire, departing from Lisbon and following the route to Goa, Kochi, Malacca, Manila, Acapulco, Mexico City, Veracruz, Havana, Sanlúcar de Barrameda and Seville, before reaching Lisbon in 1601 (Loyola, 1989; Teixeira, 1994: 355-472).

One area where the union of the crowns was soon forced to test its effectiveness was in military defence, as beginning in the early $17^{\text {th }}$ century, it was necessary to deal with the aggressive presence of Dutch ships. In fact, significantly, the Dutch made their first attack the year after founding their East India Company in 1602, on Goa, capital of Portuguese India. This was two years before Admiral Cornelis Maatalief would occupy the entire Moluccas archipelago, expelling the Portuguese from the islands of Ambon, Ternate and Tidore. An offensive on such a scale mobilized the Spanish in the Philippines. Their governor, Pedro Bravo de Acuña (1602-1606), headed up an expedition which set off from the port at Oton (on the island of Panay) on January $23^{\text {rd }}, 1606$. A force numbering three thousand men dis- embarked on Ternate, obtaining a decisive victory over the sultan, retaking the island and imposing compliance with Spanish sovereignty on the Sultan of Tidore. These events marked the beginning of a policy of systematic occupation, maintaining a resident governor on Ternate and constructing a network of fortifications to prevent a Dutch counteroffensive. This action was celebrated by the pen of Bartolomé Leonardo de Argensola in his famous work Conquista de las Islas Malucas (The Discovery and Conquest of the Molucco and Philippine Islands), written at the behest of the Count of Lemos - at the time chairman of the Council of the Indies - and published in Madrid in 1609 (Argensola, 1992; Israel, 1982; Centenero de Arce and Terrasa Lozano, 2009).

However, Spanish actions during the period of the union of the crowns were not limited to defending the Pacific holdings of Spain and Portugal against the threat of the Dutch East India Company. This period also saw the first trade and diplomatic contacts established by the Spanish with the Kingdom of Siam. The first embassy to the Siamese kingdom was the result of the personal initiative of governor Santiago de Vera (1584-1590). After notifying Philip II that he had sent missions of peace to the "kings of the region of Borneo, Mindanao, Siam", he stated with regard to the last of these states: "I have had a report that the king wished to send ships to these islands and on them have talks and our friendship. Let a ship be sent with some gift and present, offering him what has been offered to others on behalf of HM and let us try to open up the route." We do not know if this proposal to establish a new trade route was successful, although we do have reports of ships arriving in Manila from that kingdom in subsequent years. In 1598, governor Francisco Tello de Guzmán (1596-1602) sent another embassy led by his nephew, Juan Tello de Aguirre. He obtained a trade agreement with King Naresuan of Ayutthaya which, according to the letter sent to Philip II by the governor, left the "port open for Spaniards to go and freely settle there, tax-free". However, the sudden arrival of the Dutch in the area prevented the treaty from being realized and began a period of conflict which reduced traffic between Siam and the Philippines to a very limited flow. According to Antonio de Morga, at the beginning of the century, it was reduced to "a little benzoin, pepper, ivory, some cotton blankets, rubies, poorly cut set sapphires and a few slaves, rhinoceros horns, and the skins, nails and molars of that animal", products which were always exchanged for American silver (Rodao, 1997). While Spain always attempted to conduct its relations with Siam along friendly lines, mainly by signing trade agreements, the Spanish presence in the Kingdom of Cambodia was dominated by war. In fact, relations were initiated by a call for help against Siam's policy of aggression, sent by King Paramaja II in 1593. According to Antonio de Morga, the request sent to the governor of the Philippines, Gómez Pérez Dasmariñas (1590-1593), offered him "friendship and trade in his land [...] asking for assistance against Siam, which was threatening him". The 
governor decided not to intervene in an enterprise which he deemed risky. This would later be considered a lost opportunity, as the procurator general of the Philippines, Hernando de los Ríos Coronel, would point out in 1621. He believed that the expedition to Cambodia would have given Philip II not only the friendship of that kingdom, but also the crown of Siam: "If it had been done, it would have been a stroke of luck and Your Majesty would be king of Siam, which is very rich" (Morga, 1997).

Lacking Philippine support, the five Portuguese and Spanish soldiers who took part in the action could not prevent the destruction of Lovek, the Cambodian capital, and the kingdom from becoming subject to Siamese interference from that point forward, although they all survived and managed to return to Manila. After that, the successive governors of the Philippines opted to support the Cambodian sovereigns in their efforts to shake off the Thai yoke. They declared themselves in favour of direct intervention, which took the form of a series of military expeditions. The first, in 1596, was led by Juan Juárez Gallinato. It concluded without achieving its aims with an extraordinary withdrawal to the lands of present-day Vietnam (Champa and Tonkin). The second expedition was dispatched in 1598 under the command of Luis Pérez Dasmariñas, son of the former governor. Despite his extensive experience in military conflicts in the area, he was also unable to obtain any positive results, even after a number of particularly bloody episodes. The third and last, less noteworthy and unsuccessful, was launched under the leadership of Juan Díaz in 1603 (Boxer, 1969; Rodao, 1997: 12-38; Valladares, 2001: 17-18).

The ultimate failure of the Cambodia enterprise did not prevent some of its most noteworthy events from having a significant impact on Spanish public opinion. People were able to learn of the adventures taking place in such distant lands through the accounts of two eyewitnesses, Fray Gabriel de San Antonio, author of Breve y verdadera relación de los sucesos de Camboya (A Brief and Truthful Relation of Events in the Kingdom of Cambodia), published in Valladolid in 1604; and Fray Diego Aduarte, who included another recounting of events in Cambodia in his Historia de la provincia del Santo Rosario de la Orden de Predicadores en Filipinas, Japón y China (History of the Dominican Province of the Holy Rosary in the Philippines, Japan and China), published in Manila in 1640. The subject would ultimately be taken up by the Spanish literature of the period, specifically, by Luis de Góngora, Andrés de Claramonte and Miguel de Cervantes (San Antonio, 1988; Aduarte, 1962).

Nor was the military adventure in Cambodia an obstacle which inhibited the evangelizing desire of the brothers in Manila to establish themselves in Southeast Asia. It appears that the first expedition departed in 1581, led by Augustinian friars Diego de Oropesa and Bartolomé Ruiz. They travelled to the coast of Vietnam, but were expelled by the Portuguese, who were defend- ing the prerogatives of the patriarch of the East Indies. Other reports describe activities in the Kingdom of Champa by Pedro Ordóñez de Cevallos, author of Tratado de las relaciones verdaderas de las regiones de China, Cochinchina y Champan (Treatise on True Relations in the Regions of China, Cochinchina and Champan), published in Jaén in 1628. Lastly, in the $18^{\text {th }}$ century, the experience of Dominican Juan Ventura is noteworthy. He made the traditional voyage, following the route from Cádiz to Veracruz, Mexico City, Acapulco and Manila, before continuing on to Canton and from there, crossing southern China to the Kingdom of Tonkin, where he performed his missionary duties between 1715 and 1724, the year of his death (Órdoñez de Cevallos, 1628; Muñoz, 1958).

However, despite this trend of Spaniards travelling to Southeast Asia, the main field of action for the Philippine governors was the Japanese empire (Hall, 1991). Here, the Spanish presence made quite a late appearance in comparison with the Portuguese. This was despite the fact that the most important figure in the rapid spread of Christianity was a Spanish Jesuit, St Francis Xavier, whose preaching produced the spectacular result of one hundred thousand converts in just a short time, operating from a base at Nagasaki. However, the assertion of absolutism during the Momoyama period unleashed the first persecution of the Christians. It was decreed by Toyotomi Hideyoshi, who in 1587 declared Christianity a "pernicious doctrine" and ordered the expulsion of all missionaries. Things seemed to return to the earlier situation thanks to the embassy sent to Manila in 1592 by the Japanese ruler himself. It was led by Harada Magoshichiro, and was reciprocated in the form of the mission of Dominican Juan Cobo, who disappeared at sea while returning to Manila that same year. There was also a second embassy headed by Harada Kikuyemon, which reached Manila in 1593. It resulted in an important agreement obtained by governor Gómez Pérez Dasmariñas to send Franciscan missionaries to Japan to counteract the actions of the Portuguese Jesuits, having resolved the thorny question of demarcation in the Treaty of Tordesillas, as the Japanese archipelago was located to the north and east of the Philippines, and therefore, in the part of the world under the Spanish sphere of influence. This gave way to a golden age of Franciscan proselytizing, which swiftly expanded from the base at Nagasaki (although always in competition with the Jesuits arriving from Goa), and good relations between the two countries. This situation was sanctioned by a series of Spanish embassies to Japan, headed by Pedro Bautista, Pedro González de Carvajal, Jerónimo de Jesús and Luis de Navarrete, respectively (Boxer, 1951; Cabezas, 1994; Lisón Tolosana, 2005; Sánchez \& Fuertes, 1979).

However, this peaceful environment was abruptly interrupted by the resumption of persecution by Hideyoshi, who took firm action. In late 1596, the wreck of the galleon San Felipe off the Japanese coast triggered the ruler's suspicions. He felt threatened by the com- 
bined actions of the merchants and missionaries and reacted by ordering the famous crucifixion of the "twentyseven martyrs of Japan", which brought an end to the first stage of parallel Spanish diplomatic and evangelical activity. The tale of the cruel torture of the Christians (six Franciscans, three Jesuits and seventeen Japanese lay people, crucified in Nagasaki in February 1597) would be recounted by Franciscan missionary Marcelo Ribadeneyra in the penultimate section of a book intended to given an account of the past and present of the remote Asian lands, his Historia de las islas del archipiélago y reinos de la Gran China, Tartaria, Cuchinchina, Malaca, Sian, Camboxa y Jappón (History of the Philippines and Other Kingdoms), published in Barcelona in 1601 (Ribadeneyra, 1947; Berry, 1982).

Despite everything, the martyrdom at Nagasaki did not yet mean the end of either trade or Christianity in Japanese lands. The second phase of rapprochement between Japan and Spain took place during the period when the Tokugawa shogunate was taking shape (specifically, under the shoguns Ieyasu and Hidetada). The re-establishment of relations was the work of Franciscan Fray Jerónimo de Jesús. In 1599, he obtained a letter from Ieyasu to governor Francisco Tello de Guzmán requesting that a regular trade route be set up between Manila and Edo. He asked that pilots and wooden boat builders be sent to train the Japanese in navigation and boat building, as well as miners to improve operations in the silver mines. In 1602, a second letter from Ieyasu was carried to the new governor, Pedro Bravo de Acuña (1602-1606) by Franciscan Fray Pedro Burguillos. In it, he insisted on two crucial proposals: the offer of a port for Spanish ships (for both trade between Japan and the Philippines and to serve as a port of call for the Manila Galleon) and the opening of a permanent direct trade route between Japan and New Spain. These proposals would repeatedly be the object of Japanese initiatives over the next twelve years. The Spanish response was to agree to send one boat a year, demand good treatment of Franciscan missionaries and a firm response to the Dutch of the East India Company, and delay the issue of direct trade with New Spain, which could clearly be harmful to Manila's interests (Sola, 1999; Oliveira e Costa, 2003; Iaccarino, 2013).

Negotiations were revived when Rodrigo Vivero, interim governor of the Philippines between 1608 and 1609 , entered the arena. Not only did he view Ieyasu's proposal in a positive light, but he also had occasion to engage in a series of direct conversations with the Japanese leaders when the galleon San Francisco, which was to return him to New Spain in 1609, accidentally landed on the Japanese coast. His requests for friendship between the two countries and Franciscan evangelizing were well received by the courts at Edo (headquarters of the shogun Hidetada) and Suraga (residence of Ieyasu, who despite his abdication, retained enormous power), although the same could not be said of his pressure to resist the Dutch. In the end, the trade issues were left to an embassy headed by Fray Alonso Muñoz, which travelled to Spain via Mexico in 1611 with two letters (from Ieyasu and Hidetada) for the Duke of Lerma, which are held in the General Archive of the Indies. They proposed peace between Spain and Japan, instituting one ship a year between a Japanese port (the port at Usuki on Kyushu Island had previously been used) and Manila, negotiating a ship that would sail from Japan directly to New Spain and the possibility of the free settlement of religious brothers in Tokugawa domains. That same year, Sebastián Vizcaíno escorted the Japanese legation back to Japan after their visit to New Spain. He took advantage of the opportunity to revisit the courts at Edo and Suraga and surveyed the eastern ports of Honshu Island. This journey brought him into contact with the lord of Sendai, Daté Masamune, leading to the second Japanese embassy to Spain (Monbeig, 1972; Mathes, 1973).

The embassy, officially initiated by the daimyo of Sendai, with the knowledge and approval of the Edo court, was led by Tsunenaga Hasekura Rokuyemon and Fray Luis Sotelo, reaching Seville in 1614. They left behind the famous letter in the Seville Municipal Archives and some of the members of the ambassador's retinue settled in the town of Coria del Río. Negotiations were again undertaken based on the offering of perpetual peace between Japan and Spain, in exchange for an annual ship to New Spain. However, they now also requested that pilots, sailors and Spanish religious brothers be sent to Japan, in an amalgam that combined practical reasons with spiritual arguments. After a month's stay in the city of Seville, the embassy travelled to Madrid (where they were received by Philip III in January 1615) and then on to Rome (where they were welcomed by Pope Paul V in November of the same year). They returned to Seville, from where they departed (after a stay by Hasekura at the Franciscan Monastery of Loreto de Espartinas) for New Spain (in July 1617). From there, they continued on the Japan, with the leader of the expedition landing in his homeland after an absence of more than seven years (Fernández Gómez, 1998; Oizumi, 1994; 1998, 1999, 2005, 2010; Oizumi \& Gil, 2011; Takizawa, 2008; Soler del Campo, 2003).

However, despite all of these promising signs, including the spectacular nature and lengthy duration of the embassies to Philip III, these years signalled the failure of the rapprochement between Tokugawa Japan and Hapsburg Spain. Firstly, a conclusive Spanish response was precluded by the reluctance on the part of those who benefitted from the Manila Galleon to allow the opening of another route they considered a rival. Secondly, the breakdown in relations took place within the context of a radical shift in Japanese policy, which in little more than two decades would immerse the country in complete isolation. This was done by abolishing all overseas travel, violently eradicating Christianity following a long and bloody persecution which subjected the faithful to death or silence (including the "great martyrdom" of Nagasaki in 1622), and absolutely prohibiting Iberian trade in favour of trade with the Dutch 
(1639). We have evidence of this crucial moment in the accounts of the travels of Rodrigo Vivero and Sebastián Vizcaíno (which remained in their handwritten form for a very long time) and the more numerous works published to spread the word about the religious persecution. Examples include the work by Diego de San Francisco, a religious who was kept captive and possibly tortured. He reported on the culminating period of repression (1613-1624) in his widely read Relación verdadera $y$ breve de la persecución... en Japón de 15 religiosos de la provincia de San Gregorio (True and Brief Account of the Persecution ... in Japan of Religious Brothers from the Province of San Gregorio, published in Manila in 1625 and republished in Mexico twice in the following year. This is amazing evidence of the events which would bring the "Christian century" in Japan to an end (Boxer, 1951; Cabezas, 1995; San Francisco, 1914). Despite everything, the presence of missionaries in Japan had another unique outcome: it allowed a Spaniard to be the first European to visit the Kingdom of Korea. Indeed, Madrid Jesuit Gregorio de Céspedes, who had reached the Far East by taking the Portuguese route via Goa, Macau and Nagasaki, was able to set off for Korea with the help of the Catholic Japanese daimios. There he witnessed the invasion of the country by the troops of Toyotomi Hideyoshi. He wrote four letters from Korea. His primary intention was to denounce the war undertaken by the Japanese leader and give an account of some of the circumstances of the conflict, as well as the subsequent peace negotiations. However, they also have unquestionable historiographical value, as they include the first reports on Korea given by a European eyewitness. As a result, his information was used by Luis de Guzmán to write one of the passages in his Historia de las misiones que han hecho los religiosos de la Compañía de Jesús para predicar el Santo Evangelio en los Reinos de Japón (History of the Missions of the Company of Jesus in Eastern India, China and Japan), published in Alcalá de Henares in 1601 (Guzmán, 1601; Chul, 1993). While Portuguese independence in 1640 marked a turning point for the Spanish presence on the Asian continent, contact was reinitiated in the $18^{\text {th }}$ century. This revitalization of political and diplomatic action in the area is borne out by the resumption of previous relations with the Kingdom of Siam, on the initiative of governor Fernando Manuel de Bustamante. He managed to sign a new trade agreement with the government of Ayutthaya by sending an embassy headed by his nephew, Gregorio Alejandro de Bustamante, in 1718 (Díaz de Villegas, 1967; Silos Rodríguez, 2005). In addition, late in the century, the corvette Atrevida, under the command of José de Bustamante, set sail from Manila to visit China as part of the activities carried out by the scientific expedition led by Alejandro Malaspina. Their stay in Macau allowed the ship's commander to make observations (including a precise description of the Portuguese colony) and produced the four drawings by Fernando Brambila with views of the town, now kept in Madrid, in the
Naval Museum and the Museum of the Americas (Sáiz, 1994: 326-331; Alfonso Mola and Martínez Shaw, 2007 : 194-200).

The spirit of the Enlightenment was especially symbolized by the last of the great Spanish enterprises, known as the Balmis Expedition (1803-1806). It spread the practice of smallpox vaccinations among various populations in the Americas, but also reached Asia. Francisco Javier Balmis landed in Manila in 1805 aboard the ship Magallanes. He then embarked on the Portuguese frigate Diligencia, bound for China. He landed in Macau with the aim of introducing the smallpox vaccine to the Middle Kingdom, given that, in his own words, "the English had not ever been able to bring the vaccine to China, despite having attempted to do so many times with the fluids they had sent from Bombay, Madras, Bengal and Malacca". Balmis remained in China until at least the end of January 1806 . He performed vaccinations in Macau (where it seems that only a total of 22 people received them) and Canton. He travelled to the second city accompanied by a young inoculated Chinese and performed the first vaccination in an atmosphere of expectation before a large audience of locals of every sex, age and position. Upon returning to Macau, the Spanish physician completed his stay, again in his own words, "spreading the vaccine, stocking up on works of natural history and observing the state of the sciences and arts among the Chinese". That is to say, he behaved like a perfect Enlightenment scientist during this new chapter in the transmission of knowledge between Spain and the Far East which had been made possible by the route between Seville and Manila (Ramírez Martín, 1999, 2002).

\section{DIRECT COMMUNICATION WITH THE MOTHER COUNTRY}

While on one hand, Manila established a wide range of relations with the neighbouring world, on the other, its economy was essentially founded on trans-Pacific trade. This was based on exchanging Mexican silver for products from China (mainly silk goods) and other Asian countries by means of a route that linked it with the port of Acapulco in New Spain. During the period of Bourbon reforms, the fact that Spain only participated in trade with the Far East indirectly, with Mexico acting as an intermediary, led Spanish authorities to consider a direct route to the Philippines from the mother country. This would be apart from the trans-Pacific route taken by the Manila Galleon. However, while the first dissenting voices regarding the nonexistent benefits of the Manila Galleon for the mother country were heard in the late $16^{\text {th }}$ century, continuing with the arbitrista reformers in the $17^{\text {th }}$ century, it was not until the $18^{\text {th }}$ century that there was any real reaction in Spain. This took the form of the emergence of economic literature that generated a succession of trade-related plans, promoted at the highest levels of government and supported by individuals (Alfonso Mola and Martínez Shaw, 2013a). 
Broadly speaking, the economic literature of the $18^{\text {th }}$ century proposed realigning the Philippine economy based on three areas of action: The first was the development of production on the islands themselves to cancel out the effects of so-called passive trade, in other words, the deficit produced when highly valuable imports have no counterpart in local goods, resulting in currency flight. The second was strengthening regional trade as a means of diversifying commercial exchange, alleviating the dependence on Chinese suppliers, achieving a more balanced flow of imports and exports and reducing the drain of silver. And the third involved shifting part of the traditional commerce of the Manila Galleon from Mexico to Cádiz as a way to establish direct traffic not only between the mother country and the Philippines, but also between Spain and other Asian markets. This brought an end to the monopoly of the Spanish colonists on the archipelago, abolished the exclusive rights of the Mexican merchants on the other side of the Pacific, promoted multilateral commercial exchange and allowed Spanish interests access to the area of Asia from which Spanish trade had been excluded and which was being exploited by other European powers (Alfonso Mola and Martínez Shaw, 2013b). And so the possibility of an alternate route to the Manila Galleon began to take shape. The process, long in the planning stages, was accelerated when the city of Manila was occupied by England between 1762 and 1764. This served as a wakeup call for the Spanish authorities, who then grasped the structural fragility at the outer reaches of its imperial system and the need to introduce an extensive programme of reforms to ensure its continued existence. Indeed, the English occupation of Manila (1762-1764) during the Seven Years' War and the delay in returning control to Spain would influence the stages and forms of trade liberalization in the Pacific sphere. Now, the economic interests that had been insinuating themselves over the previous three decades would be reinforced by urgent military requirements. In other words, they benefitted from the need to significantly improve the defence of the islands and guarantee a direct route to send any aid from the peninsula that might be necessary in the event any threat from foreign powers, particularly England, reappeared (Tracy, 1995).

Thus, beginning in 1765, without shutting down the traditional route of the Manila Galleon, the Spanish crown decided to open up a direct route from Spain to the Philippines. It would depart from Cádiz (the new headquarters of the monopoly on Spanish overseas trade) and reach Manila via the Cape of Good Hope (a route prohibited to the Spanish since the Treaty of Tordesillas in 1494). The route was gradually implemented in several stages. The first involved sending a number of Navy vessels straight to the archipelago via the Cape of Good Hope route between 1765 and 1784. In the second, licences for direct trade with Manila were granted to different private firms: the Five Major Guilds of Madrid Company (Compañia de los Cinco Gremios Mayores de Madrid) and Ustáriz y Llano San Ginés. In the third and last stage, the monopoly for the route was granted to a single privileged company, the Royal Company of the Philippines (Real Compañía de Filipinas), in 1785 (Díaz-Trechuelo, 1963). The Navy ships inaugurated the Cádiz-Manila route in 1765 and made 14 return voyages in 20 years. The expeditions sailed aboard the following ships (some of which made more than one voyage): the vessel El Buen Consejo; the frigates Venus, Astrea, Palas and Juno and the hooker Santa Inés. Some of these voyages included two stops at commercial ports of call in India: Tranquebar (a Danish colony on the Coromandel Coast, founded in 1616 as comptoir of the Danish East India Company) and Calcutta (on the Bay of Bengal, headquarters of England's East India Company) (Alfonso Mola and Martínez Shaw, 2013c). In this context, it is interesting to make special note of the preparations for the first Navy ship to make the voyage to Asia, El Buen Consejo (60 cannons, 2 decks, launched in 1761). For the process is indicative of all the problems involved in fitting a ship out and providing it with a crew, provisions and food, as well as the diplomatic problems resulting from implementing this government initiative. Minister of the Navy Julián de Arriaga used the via reservada system, which gave him direct access to the king, to charge quartermaster Juan Gerbaut with finding out what ships were available at the port of Cádiz to undertake the enterprise, and about the availability of crew members (200 men), the existence of pilots capable of carrying out such a complex voyage, the possibility of obtaining the food supplies and medicines for the long voyage, the necessary ports of call and the most suitable dates for setting sail from both ends of the return voyage. This he did through frigate captain Juan de Caséns. The inquiries were conducted in secret, reaching the conclusion that it was possible to find everything required in Cádiz, as it was a port town with extensive experience in preparing ships for the Indies Route. However, the sole exception was the pilots. In fact, as it was a new route, there were no Spanish pilots capable of taking on the enterprise. This forced the authorities to seek advice on the practices used by the ships of the French and Swedish East India companies. They ultimately opted for the French (possibly because of the guarantees offered by the shared ancestry of the reigning dynasties in the two countries), who were experts in sailing to China on ships of the company established in Lorient. After a lengthy outward voyage, El Buen Consejo landed successfully in Manila, from which it returned, also without mishap (Martínez Shaw and Alfonso Mola, 2013).

Focusing on mercantile aspects, the naval expeditions (1765-1784) that opened up the Cádiz-Manila route offer a number of interesting lessons. Firstly, although they exercised caution, Cádiz merchants responded to the call and loaded a small amount of products bound for the Philippines (a little wine, spirits and oil and a few quintals of iron). And more importantly, they received abundant supplies of Asian goods in return, notably cotton textiles, silk cloth, silk in all its varieties, spices 
(cinnamon, pepper), sappanwood and ceramics. The termination of the exclusive rights of the Manila Galleon route and promotion of an alternate route made the hostility of the Philippine merchants perfectly justified. However, this first adventure in direct trade led only to the acceptance and, to a certain extent, the confirmation of a system of trade based on the exclusive sale of Asian goods, especially those from China, by merchants established in the capital of the archipelago. As such, Acapulco remained the undisputed terminus of New Spain. Meanwhile, Cádiz was barely making its debut as a Spanish terminus and was still in its infancy, regardless of how much this first concrete measure of the desire for change which had been expressed for some decades generated more than logical uncertainty regarding the future among those who benefitted from the Manila Galleon (Cosano Moya, 1981; 1983). 1784 brought an end to the series of expeditions made aboard war ships which combined strategic, scientific and commercial interests. They were an excellent test run for exploring a route denied to the Spanish Navy for more than two and a half centuries, and for learning about the economic, and especially the mercantile, situation of the Philippine Islands. It also gave Cádiz merchants their first experience of direct trade between the city and the remote confines of Asia, and demonstrated that this voyage was shorter than the system currently in place (the round trip, including lay days, had been reduced to eighteen months). The Philippine Islands, and with them all the trade of the Far East, were now closer (Bernabeu Albert, 1987). After the new route was established, as was to be expected, there was complete opposition by other European powers with commercial interests in the East, as well as those who benefitted from the Manila Galleon trade. The Spanish authorities were aware of an existing issue, the likely challenge by other nations, especially the United Provinces, to Spain's right to sail around the Cape of Good Hope. While it is certain that Spanish leaders did not lose sleep over the complaints, which at no time put the expedition in doubt, it is also certain that the issue was the subject of intense debate in certain quarters (and over quite a long period). It was some time before the dispute was resolved. This is demonstrated by the fact that the States-General of the United Provinces still denied the legitimacy of Spanish ships taking the Cape route in 1786, at the request of the Dutch East India Company (VOC), when the Royal Company of the Philippines began sailing this route (Alfonso Mola and Martínez Shaw, 2013c).

After the Navy ships stage, the commercial route to Manila was opened up to companies authorized by Charles III to trade between Cádiz and the Pacific sphere. The Five Major Guilds of Madrid Company only joined the operation after the route had been fully established by the Navy. While the Navy ships fulfilled military, scientific and commercial functions, trade activity was the only reason for this entirely different series of voyages undertaken between Cádiz and Manila along the Cape of Good Hope route. The first of- ficial licence for this traffic was issued in 1776 to the Five Major Guilds of Madrid Company. The company was granted the authority to register goods on the Navy ships bound for the Philippines and in the future, to charter its own ships, as well as setting up two agents in Manila and Canton. The second licence for direct trade with Manila was granted to the Cádiz firm Ustáriz y Llano San Ginés in 1779. It was authorized to send riches, fruit and other goods from Cádiz and import spices, silk goods and cotton textiles from Manila. To this end, that same year, the vessel San Francisco de Paula (a) Hércules set sail on behalf of the company. When it landed in Manila, it was surprised by the declaration of war by the Thirteen Colonies. As a result, it opted to forgo returning to Spain and dedicate its energies to another type of trade, requesting and obtaining authorization from the governor, José Basco y Vargas, to sail to Canton to purchase Chinese products, and then on to Acapulco (as well as Guayaquil and El Callao) to sell them, thus disrupting the monopoly of the Manila Galleon on trade between Asia and the Americas. In 1783, the ship departed again, this time for Macau. It left there in 1784, headed back to Acapulco, reaching San Blas before undertaking a further voyage to Paita and El Callao, where it arrived the following year. The adventure of the San Francisco de Paula (a) Hércules is not therefore a mere anecdote. Rather, its primary value lies in representing a preview of the system of trade which would gradually be established by the Royal Company of the Philippines beginning in 1785 (although it was carried out on an exceptional basis by obtaining individual authorization from the governor of the archipelago after being rejected by the Manila Merchant Guild) (Capella and Matilla Tascón, 1957; Ruiz Rivera, 1976; Herrero Gil, 2008-2009, 2013).

Lastly, authorization to found the Royal Company of the Philippines had been granted by Charles III, as indicated in article 50 of its articles of association, with "the special object of the good of my beloved subjects and of promoting agriculture and industry in the Philippines". This required the company to invest four percent of its annual profits in the archipelago, in specifically developing these two areas. The presence of the Royal Company of the Philippines meant the end of the "Nao de China" monopoly, as it combined trade expeditions along the traditional route and those that sailed apart from the Manila Galleon route. The Cádiz-Manila voyage was initiated in September 1785 by the frigate Nuestra Señora de los Placeres, which following the Cape Horn route, while the frigates Nuestra Señora de las Nieves and El Águila Imperial set sail in January of the following year, taking the Cape of Good Hope route and reaching the Philippines in August (Díaz Trechuelo, 1965). The Company spared no effort in attempting to expand its concessions. As a result, five years later (1790), it succeeded in having the obligation to make port in Manila abolished. That is to say, it obtained the right to direct trade between Spain and India and China, 
an authorization which would be ratified by royal order on July 12th, 1803, confirming the privileges (article 60). Of these two new lines, the first was effectively opened in 1796, with an eventful voyage which carried the commissioner in India to Île-de-France (Mauritius) - from where he sent a shipment of Asian textiles, coffee and pepper from the Malabar Coast to Cádiz - before landing on the Coromandel Coast, first at the Danish colony of Tranquebar and then at the English colony of Madras. He then permanently settled in Calcutta as an agent of the Royal Company. After this, the CádizTranquebar-Calcutta line acquired a certain degree of regularity, with some variations. There were numerous expeditions between 1797 and 1818 (aboard the vessel Columbus, the frigates Clive, Ifigenia, Princesa de Asturias and Nuestra Señora del Buen Suceso (a) La Esperanza and the vessel San Julián), to the extent that it became one of the most travelled and among the most profitable routes of those opened by the company. Therefore, a large part of its business excluded Manila and of course, the Acapulco route. The Royal Company of the Philippines soon established a permanent trading post in Canton. Together with those in Manila and Calcutta (which also had a branch on the Coromandel Coast from 1818), they made up the framework of permanent establishments in Asia. Preferably, the trading post acted as a shipping agent office (not only for company ships, but also those of others), both when purchasing Chinese goods (tea, silks, ceramics) bound for Manila and when finding a buyer for products from the Philippines in China. In addition to these functions, the trading post could also be used for direct trade between Cádiz and Canton, without the involvement of Manila. However, although royal orders issued in 1790 and 1803 also envisaged the opening up of China together with India, the route never worked, regardless of how much Canton might provide excellent services for direct relations between Asia and the America, again excluding the Manila Galleon (Ugartemendia, 2012). In short, in the late $18^{\text {th }}$ century, the dispute between Spanish interests and combined Philippine and Mexican interests was settled with one agreement: the continued existence of the traditional trade with New Spain would coexist with legally established direct trade with the mother country. Meanwhile, another set of measures substantially expanded the role of the port of Manila in international maritime trade. And so the port of Manila experienced a gradual recovery after beginning to allow Asian ships in 1785. In 1790, it began allowing ships flying under any flag, provided that they were not transporting European goods. And in 1793, it began allowing ships and goods of any origin, especially during periods of military conflict, with the resulting supply problems (Martínez Shaw, 2007). It was the independence process in the Americas that brought the Manila Galleon route to an end. In December 1811, the galleon Magallanes found Acapulco paralyzed by war and she prepared to withstand what was expected to be a long stay. In 1813, the Spanish authorities responded to the situation by ordering the suspension of traffic between the Philippines and Mexico. In 1815, the Magallanes set sail to complete its final voyage from the New Spain port to the Philippine capital. Nonetheless, traffic was not interrupted. Not even the official suspension of the Manila Galleon (by decree of the Parliament of Cádiz (Cortes de Cádiz) on September 14th, 1813, ratified by a new decree by Ferdinand VII on April 23rd, 1815) meant the death of the route. It continued to benefit from the inertia of past centuries, taking advantage of the alternative concessions contained in these decrees, which authorized individual ships to travel from Manila to Acapulco, San Blas and Sonsonate. In fact, a document from the Acapulco Public Treasury (dated September 20th, 1820) gives a "report of the shipments brought to Acapulco by trade vessels from Manila from the years 1815 to 1818 ". It recorded a total of seven ships present in the Mexican port: the frigate Victoria, the brigantine Feliz, the frigate Maria, the frigate Victoria (for a second time), the frigate María (for a second time), the frigate $P a z$ and the covette Espina. What is more, we have reports that in 1820 there were still Spanish ships from the Far East in both the port of Acapulco and the port of El Callao. Therefore, the route did not shut down until it was absolutely impossible the keep it active. Likewise, between 1790 and 1820, Manila not only remained the centre of the Spanish Pacific, but it was also one of the largest ports of trade in Asia and the major distribution centre for silver in the Far East (Yuste, 2000; Martínez Shaw, 2007). In 1820, this long history came to its final conclusion: the history of the Seville (or Cádiz)-Veracruz-Mexico City-Acapulco-Manila axis, with activity in both directions, which had served as a permanent route for the movement of men and women, for the exchange of precious metals and exotic products, and as an avenue for cultural transfers of all kinds among Spain, Spanish America and Spanish Asia throughout the early modern period. And as such, it had made the Philippine Islands one of the major crossroads of the first globalization.

\section{NOTES}

1. For the study of the "sangleyes" or Chinese from the Philippines: Gil, 2011 and García-Abásolo, 2012. For the "Parián de los Sangleyes", see: Ollé, 2008.

2. Some examples of the literature on Spanish silver: Chaunu (1960); Chuan (1969); Attman (1981); Barrett (1983); Te Paske (1983); Valdés Lakowsky (1987); Flynn (1996); Flynn \& Giráldez (1996); Fradera (2001). For the commercial relations between Manila and Macao see: Boxer (1959); and Ollé (2000b).

\section{REFERENCES}

Aduarte, Diego (1962) Historia de la provincia del Santo Rosario de la Orden de Predicadores en Filipinas, Japón y China. CSIC, Madrid (original edition, 1640).

Alfonso Mola, Marina and Martínez Shaw, Carlos (editors), (2000) El Galeón de Manila. Catálogo. Aldeasa, Madrid. 
Alfonso Mola, Marina and Martínez Shaw, Carlos (editors), (2003) Oriente en Palacio. Tesoros asiáticos en las Colecciones Reales españolas. Catálogo. El Viso, Madrid.

Alfonso Mola, Marina and Martínez Shaw, Carlos (2004) "La era de la plata española en Extremo Oriente". Revista Española del Pacífico, No. 17: 33-53.

Alfonso Mola, Marina and Martínez Shaw, Carlos (editors), (2007) La ruta española a China. Relaciones entre España y China en los tiempos modernos. El Viso, Madrid.

Alfonso Mola, Marina and Martínez Shaw, Carlos (2013a) "La reorientación de la economía filipina en el proyectismo del siglo XVIII". In Homenaje a Juan Luis Castellano. Servicio de Publicaciones de la Universidad de Granada, Granada: 539-557.

Alfonso Mola, Marina and Martínez Shaw, Carlos (2013b) "España y el comercio de Asia en el siglo XVIII. Comercio directo frente a comercio transpacífico". In El sistema comercial español en la economía mundial (siglos XVII-XVIII), eds. Oliva, José María ans Lobato, Isabel. Servicio de Publicaciones de la Universidad de Huelva, Huelva: 325-380.

Alfonso Mola, Marina and Martínez Shaw, Carlos (2013c) "La ruta del Cabo y el comercio español con Filipinas". In Un océano de seda y plata: el universo económico del Galeón de Manila, eds. Bernabéu Albert, Salvador and Martínez Shaw, Carlos. EEHA/CSIC, Madrid: 307-340.

Alonso Álvarez, Luis (2004) "La política de Legazpi y su proyección: la formación del proyecto español en las islas Filipinas, 1565-1593". In España y el Pacífico. Legazpi, doord. Cabrero, Leoncio. Sociedad Estatal de Conmemoraciones Históricas, Madrid, t. I: 437-462.

Alonso Álvarez, Luis (2009) El costo del imperio asiático. La formación colonial de las islas Filipinas bajo el dominio español, 1565-1800. Servicio de Publicaciones de la Universidad de La Coruña, Corunna.

Alonso Álvarez, Luis (2013) "E la nave va. Economía, fiscalidad e inflación en las regulaciones de la carrera de la Mar del Sur, 1565-1604". In Un océano de seda y plata. El universo económico del Galeón de Manila, eds. Bernabéu Albert, Salvador and Martínez Shaw, Carlos. EEHA/CSIC, Madrid: 25-84.

Attman, Artur (1981) The Bullion Flow between Europe and the East, 1000-1750. Kungliga Vetenskaps, Göteborg.

Atwell, W. (1988) "Ming China and the emergent World Economy, ca. 1470-1650". In The Cambridge History of China, vol 8: The Ming Dynasty, 1368-1644, part 2, eds. Twitchwtt, E. and Motte, F.W. Cambridge University Press: 376-416.

Barret, Ward (1983) "World Bullion Flow, 1450-1800". In Precious Metals in the Later Medieval and Early Modern World, ed. Richards, J.F. Carolina Academic Press, Durham, N.C.: 224-255.

Bernabéu Albert, Salvador (1987) "Ciencia ilustrada y nuevas rutas. Las expediciones de Juan de Lángara al Pacífico, 1765-1773. Revista de Indias, No. 180: 447-467.

Bernabeu Albert, Salvador and Martínez Shaw, Carlos (editors), (2013) Un océano de seda y plata. El universo económico del Galeón de Manila. EEHA/CSIC, Seville.

Bernal, Antonio-Miguel (2004) 'La 'Carrera del Pacífico' Filipinas en el sistema colonial”. España y el Pacífico. Legazpi, directed by Cabrero Leoncio. Sociedad Estatal de Conmemoraciones Culturales, t. I: 485-525.

Berry, Elizabeth (1982) Hideyoshi. Harvard University Press, Cambridge (Mass.)

Borah, Woodrow (1975) Comercio y navegación entre México y Perú en el siglo XVI. Instituto Mexicano de comercio exterior. Mexico.

Boxer, Charles Ralph (1951) The Christian Century in Japan, 1549-1650. University of California Press, Berkeley.

Boxer, Charles Ralph (1959) The Great Ship from Amacon. Annals of Macao and the Old Japan Trade, 1555-1640. Centro de Estudos Históricos Ultramarinos, Lisbon.

Boxer, Charles Ralph (1969) "Portuguese and Spanish Projects for the Conquest of Southeast Asia". Journal of Asian History, vol. 3: $118-136$

Cabezas, Antonio (1995) El Siglo Ibérico de Japón. La presencia hispano-portuguesa en Japón (1543-1643). Universidad de Valladolid, Valladolid.
Cabrero, Leoncio (coordinator), (2000) Historia General de Filipinas. Ediciones de Cultura Hispánica, Madrid.

Cabrero, Leoncio (director), (2004) España y el Pacífico. Legazpi. Sociedad Estatal de Conmemoraciones Culturales, Madrid.

Capella, Miguel and Matilla Tascón, Antonio (1957) Los Cinco Gremios Mayores de Madrid. Estudio histórico-crítico. Imprenta Sáez, Madrid.

Cárdenas de la Peña, Enrique (1965) Urdaneta y el tornaviaje. Secretaría de Marina, Mexico D.F.

Centenero de Arce, Domingo and Terrasa Lozano, Antonio (2009) "Una república, una monarquía, dos imperios bajo una misma cabeza y una isla de las especias. Las relaciones luso-hispanas entre 1580-1621". Anais de História de Além Mar, vol IX: 289-332.

Chaunu, Pierre (1960) Les Philippines et le Pacifique des Ibériques (XVI, XVII, XVIII siècles). S.E.V.P.E.N., Paris.

Chuan, H.-S. (1969) "The inflow of American silver into China from the late Ming to the mid-Ch'ing Period". Journal of the Institute of Chinese Studies of the Chinese University of Hongkong, vol 2: 61-75.

Chul, Park (1993) "Gregorio de Céspedes, primer visitante europeo de Corea". Revista Española del Pacífico, No. 3: 139-146.

Cosano Moya, José (1981) "El comercio directo Cádiz-Manila en navíos de la Real Armada (1765-1784)". Boletín de la Real Academia de Córdoba, No. 102: 183-220.

Cosano Moya, José (1983) "Hombres, mercancías y precios en el tráfico comercial directo entre España y Filipinas en la segunda mitad del siglo XVIII". Actas II Coloquios de Historia de Andalucía, Córdoba, t. I: 553-569.

Cushner, Nicholas P. (1971) Spain in the Philippines: From Conquest to Revolution. Ateneo de Manila, Quezon City.

Díaz de Villegas and Bustamante, José (1967) Una embajada española a Siam a principios del siglo XVIII. Publicaciones del Centro de Estudios Montañeses y del Instituto de Estudios Africanos, Madrid.

Díaz-Trechuelo Spínola, María Lourdes (1963) "El comercio de Filipinas durante la segunda mitad del siglo XVIII". Revista de Indias, Nos. 93-94: 463-485.

Díaz-Trechuelo Spínola, María Lourdes (1965) La Real Compañía de Filipinas. Escuela de Estudios Hispano-Americanos, Sevilla.

Fernández Gómez, Marcos (1998) "Sevilla, encrucijada entre Japón y Europa. Una embajada japonesa a comienzos del siglo XVII (Misión Keicho). Archivo Hispalense, No. 248, 33-60.

Fernández Gómez, Marcos (1999) "La Misión Keicho (1613-1620): Cipango en Europa. Una embajada japonesa en la Sevilla del siglo XVII. Studia Storica. Historia Moderna, No. 20: 269-295.

Flynn, Dennis O. (1991) "Comparing the Tokugawa Shogunate with Hapsburg Spain: Two Silver-Based Empires in a Global Setting”. In The Political Economy of Merchant Empires: State Power and World Trade, 1350-1750, ed. Tracey, James D. Cambridge University Press: 332-359

Flynn, Dennis O. (1996) World Silver and Monetary History in the 16th and 17th Centuries. Aldershot, Variorum.

Flynn, Dennis O. and Giráldez, Arturo (1996) "China and the Spanish Empire”. Revista de Historia Económica, t. XIV, No. 2: 309-338.

Fradera, Josep María (2001) "Plata americana, monedas indias". Gaceta Numismática, No. 141: 17-39.

Galván Guijo, Javier (editor), (1998) Islas del Pacífico. El legado español. Dirección General de Cooperación y Comunicación Cultural, Madrid.

García-Abásolo, Antonio (2012) Murallas de piedra y cañones de seda. Chinos en el Imperio español (siglos XVI-XVIII). Servicio de Publicaciones de la Universidad de Córdoba, Córdoba.

García-Baquero González, Antonio (1992) La Carrera de Indias. Suma de la Contratación y océano de negocios. Algaida Editores, Seville.

Gil, Juan (1991) Hidalgos y samurais. España y Japón en los siglos XVI y XVII. Alianza Editorial, Madrid.

Gil, Juan (2011) Los chinos en Manila (siglos XVI y XVII). Centro Científico e Cultural de Macau, Lisbon.

Godinho, Vitorino Magalhâes (1963-1965) Os Descobrimentos e a Economia Mundial. Editora Arcádia, Lisbon. 
González de Mendoza, Juan (1990) Historia de las cosas más notables, ritos y costumbres del gran reino de la China. Miraguano/Polifemo, Madrid (original edition, Rome, 1585).

Guzmán, Luis de (1601) Historia de las misiones que han hecho los religiosos de la Compañía de Jesús para predicar el Santo Evangelio en los Reinos de Japón. Alcalá de Henares.

Hall, J.W. (editor), (1991) The Cambridge History of Japan. 4. Early Modern Japan. Cambridge University Press, Cambridge.

Herrero Gil, María Dolores (2008-2009) “El 'Punto de Vista' o la revisión de dos viajes a Extremo Oriente: El Hércules de la Compañía gaditana Ustáriz y San Ginés”. Revista Española del Pacífico, Nos. 21-22: 89-132.

Herrero Gil, María Dolores (2013) El mundo de los negocios de Indias. Las familias Álvarez Campana y Llano San Ginés en el Cádiz del siglo XVIII. Diputación de Sevilla/Universidad de Sevilla/EEHA, Seville.

Hidalgo Nuchera, Patricio (editor), (1993) Redescubrimiento de las Islas Palaos. Miraguano/Polifemo, Madrid.

Iaccarino, Ubaldo (2013) "El papel del Galeón de Manila en el Japón de Tokugawa Ieyasu (1598-1616)". In Un océano de seda y plata. El universo económico del Galeón de Manila, eds. Bernabéu Albert, Salvador and Martínez Shaw, Carlos. EEHA/CSIC, Madrid: 133-153.

Israel, Jonathan I. (1982) The Dutch Republic and the Hispanic World, 1606-1661. Oxford University Press.

Iwasaki Cauti, Fernando (1992) Extremo Oriente y Perú en el siglo XVI. Mapfre, Madrid.

Kamiki, Tetsuo and Yamamura, Kozo (1983) "Silver mines and Sung coins. A monetary history of medieval and modern Japan in international perspective". In Precious Metals in the Later Medieval and Early Modern Worlds, ed. Richards, F.J. Carolina Academic Press, Durham, N.C.: 329-362.

Kelsey, H. (1986) "Finding the Way Home: Spanish Exploration of the Round-Trip Route across the Pacific Ocean". The Western Historical Quarterly, t. XVII: 145-164.

Kobata, Atsuchi (1965) "The Production and Uses of Gold and Silver in Sixteenth and Seventeenth Century Japan”. Economic History Review, t. XVIII, No. 2: 245-266.

Landín Carrasco, Amancio (1991) Descubrimientos españoles en el Mar del Sur. Banco Español de Crédito, Madrid.

Leonardo de Argensola, Bartolomé, Conquista de las Islas Malucas, edited by Alonso Martín (1992). Miraguano, Madrid (original edition, Madrid, 1609).

Lisón Tolosana, Carmelo (2005) La fascinación de la diferencia. La adaptación de los jesuitas al Japón de los samuráis, 1549-1592. Akal, Madrid.

Loyola, Martín Ignacio de, Viaje alrededor del mundo, edited by Tellechea Idígoras, J. Ignacio (1989). Historia 16, Madrid (original edition, Rome, 1585)

Martínez Shaw, Carlos (editor), (1988) El Pacífico Español. De Magallanes a Malaspina. Lunwerg, Barcelona.

Martínez Shaw, Carlos (2001) "La exploración española del Pacífico en los tiempos modernos". In Imperios y naciones en el Pacifico, eds. Elizalde, M.D.; Fradera, J. M. and Alonso, L. CSIC, Madrid, t. I: 3-25.

Martínez Shaw, Carlos (2007) El sistema comercial español del Pacífico (1765-1820). Discurso de Ingreso en la real Academia de la Historia. Servicio de Publicaciones de la UNED, Madrid.

Martínez Shaw, Carlos and Alfonso Mola, Marina (2013) "La Armada en el Cabo de Buena Esperanza. La primera expedición del Buen Consejo, 1765-1767". Anuario de Estudios Atlánticos, No. 59: 431-477.

Martínez Shaw, Carlos and Martínez Torres, José Antonio (editors), (2014) España y Portugal en el mundo (1580-1668). Polifemo, Madrid.

Mathes, Michael W. (1973) Sebastián Vizcaíno y la expansión española en el Océano Pacífico, 1580-1630. UNAM, Mexico D.F.

Monbeig, Juliette (1972) Rodrigo de Vivero (1564-1636). Du Japon et du bon gouvernement de l'Espagne et des Indes. S.E.V.P.E.N., Paris.
Morales, Luis de and Le Gobien, Charles Historia de las Islas Marianas, edited by Coello de la Rosa, Alexandre (2013). Polifemo, Madrid (original edition, 1700).

Morga, Antonio de Sucessos de las Islas Filipinas, edited by Hidalgo Nuchera, Patricio (1997). Polifemo, Madrid (original edition, Mexico D.F., 1609).

Muñoz, Honorio (1958) El P. Juan Ventura Díaz, O. P. Misionero dominico montañés en el reino de Tunkín, 1715-1724. Editorial Cantabria, Santander.

Myers, Ramon H. and Wang, Yeh-chien (2002) "Economic developments, 1644-1800". In The Cambridge History of China, vol 9: The Ch'ing Dynasty, part 1, ed. Peterson, Willard J. Cambridge University Press, Cambridge: 563-645.

Oizumi, José Koichi (1994) Estudios sobre la misión de la era Keicho. Bunshindo Ltd. Tokyo.

Oizumi, José Koichi (1998) Estudios académicos sobre Hasekura Tsunenaga y la misión de la era Keicho. Bunshindo Ltd. Tokyo.

Oizumi, José Koichi (1999) Hasekura Tsunenaga. Desgracias de la misión de la era Keicho. Chûkô-Shinsho. Tokyo.

Oizumi, José Koichi (2005) El objetivo verdadero de la misión de la era Keicho y de Rokuemon Hasekura. Yuzankaku Co, Tokyo.

Oizumi, José Koichi (2010) La misión secreta de Masamune Date. Yosensha Co, Tokyo.

Oizumi, José Koichi and Gil, Juan (editors), (2011) Historia de la Embajada de Idate Masamune al Papa Paulo V (1613-1615) por el Doctor Escipión Amati intérprete e historiador de la Embajada. Doce Calles, Aranjuez.

Oliveira e Costa, Joâo Paolo (2003) "Tokugawa Ieyasu and the Christian Daimyo during the Crisis of 1600". Bulletin of Portuguese/Japanese Studies, t. VII: 45-71.

Ollé, Manel (2000a) La invención de China. Percepciones y estrategias filipinas respecto a China durante el siglo XVI. Harrassowitz Verlag, Wiesbaden.

Ollé, Manel (2000b) "Competencia Macao-Manila en el contexto inicial de la monarquía dualista, 1581-1593”. Illes i Imperis, No. 3: 5-21.

Ollé, Manel (2002) La empresa de China. De la Armada Invencible al Galeón de Manila. El Acantilado, Barcelona.

Ollé, Manel (2008) "Interacción y conflicto en el Parián de Manila". Illes i Imperis, Nos. 10-11: 61-90.

Ordóñez de Cevallos, Pedro (1628) Tratado de las relaciones verdaderas de las regiones de China, Cochinchina y Champan. Jaén.

Permanyer Ugartemendia, Ander (2012) "Españoles en Cantón: los Diarios de Manuel de Agote, primer factor de la Compañía de Filipinas en China (1787-1796)". Itsas Memoria. Revista de Estudios Marítimos del País Vasco, No. 7: 523-546.

Phelan, John Leddy (1967) The Hispanization of the Philippines: Spanish Aims and Filipino Responses, 1565-1700. The University of Wisconsin Press, Madison.

Quiason, Serafin (1966) English 'Country Trade' with the Philippines, 1644-1765. University of the Philippines Press, Quezon City.

Ramírez Martín, Susana (1999) La mayor hazaña médica de la Colonia. Abya-Yala, Quito.

Ramírez Martín, Susana (2002) La salud del Imperio. La Real Expedición Filantrópica de la Vacuna. Doce Calles, Madrid.

Reid, Anthony (1993) Southeast Asia in the Age of Commerce, 1450-1680. II. Expansion and Crisis. Yale University Press, New Haven.

Ribadeneyra, Marcelo, Historia de las islas del archipiélago y reynos de la gran China, Tartaria, Cuchinchina, Malaca, Sian, Camboxa y Jappon (edited by Rodríguez Legísima, Juan (1947). La Católica, Madrid (original edition, Barcelona, 1601).

Rodao, Florentino (1997) Españoles en Siam (1540-1939). Una aportación al estudio de la presencia hispana en Asia. CSIC, Madrid.

Ruiz Rivera, Julián (1976) “La Casa Ustáriz, San Ginés y Compañía”. In La burguesía mercantil gaditana (1650-1868). Instituto de Estudios Gaditanos, Cádiz: 183-199.

Sáiz, Blanca (editor), (1994) Alejandro Malaspina. La América imposible. Compañía Literaria, Madrid. 
San Antonio, Gabriel de and Vivero, Rodrigo de Relaciones de la Camboya y el Japón, edited by Ferrando, Roberto (1988). Historia 16, Madrid (original edition, 1604).

San Francisco, Diego de (1914) Relación verdadera y breve de la persecución en Japón de 15 religiosos de la provincia de San Gregorio. Imprenta de López del Horno, Madrid (original edition, Manila, 1625).

Sánchez, Víctor and Fuertes, Cayetano S. (directors) (1979) España en Extremo Oriente. Filipinas, China, Japón: Presencia Franciscana, 1578-1978. Editorial Cisneros, Madrid.

Schurz, William Lytle (1992) El Galeón de Manila. Ediciones de Cultura Hispánica, Madrid (original English edition, 1939).

Silos Rodríguez, José María (2005) Las embajadas al Sudeste asiático del gobernador Bustamante (Filipinas, 1717-1719). Ministerio de Defensa, Madrid.

Sola, Emilio (1999) Historia de un desencuentro. España y Japón, 1580-1614. Fugaz/Prólogos, Alcalá de Henares.

Soler del Campo, Ảlvaro (2003) "Embajadas japonesas en la Real Armería”. In Oriente en Palacio. Tesoros asiáticos en las Colecciones Reales españolas. Catálogo, eds. Alfonso Mola, Marina and Martínez Shaw, Carlos. El Viso, Madrid: 59-67.

Spate, Oskar H.K. (1979-1988) The Pacific since Magellan (1. The Spanish Lake, II. Monopolists and Freebooters, III. Paradise Found and Lost). Australian National University Press, Canberra (Spanish translation of vol. I: El Lago español, Madrid, 2006).

Takizawa, Osami (2008) "La delegación diplomática enviada a Roma por el señor feudal japonés Date Masamune (1613-1620). Boletín de la Real Academia de la Historia, t. CCV, cuaderno I (January-April): 137-158.

Te Paske, John Jay (1983) "New World silver, Castile and the Philippines, 1590-1800". In Precious Metals in the Later Medieval and Early Modern Worlds, ed. Richards, J.F. Durham, N.C.: 425-445.
Teixeira, Pedro, Relaciones... de un viaje hecho por el mismo autor dende la India Oriental hasta Italia por tierra, edited by Barajas Sala, Eduardo (1994). Miraguano/Polifemo, Madrid (original edition, Antwerp, 1610).

Torre Villar, Ernesto de la (compiler), (1980) La expansión hispanoamericana en Asia. Siglos XVIy XVII. Fondo de Cultura Económica, Mexico D.F.

Tracy, Nicolas (1995) Manila Ransomed. The British Assault on Manila in the Seven Years War. University of Exeter Press, Exeter.

Truchuelo García, Susana (editor), (2009) Andrés de Urdaneta: un hombre moderno. Ayuntamiento de Ordizia, Ordizia.

Valdés Lakowsky, Vera (1987) De las Minas al Mar. Historia de la plata mexicana en Asia: 1565-1834. Fondo de Cultura Económica, Mexico D.F.

Valladares, Rafael (2002) Castilla y Portugal en Asia (1580-1680). Declive imperial y adaptación. Leuven University Press, Leuven.

Yuste López, Carmen (1984) El comercio de la Nueva España con Filipinas, 1590-1785. INAH, Mexico D.F.

Yuste López, Carmen (2000) "El eje comercial transpacífico en el siglo XVIII: la disolución imperial de una alternativa colonial". In El comercio exterior de México, 1713-1850. Entre la quiebra del sistema imperial y el surgimiento de una nación, coords. Yuste López, C. and Souto Mantecón, M. Instituto Mora, Mexico D.F.: 21-41.

Yuste López, Carmen (2007) Emporios transpacíficos. Comerciantes mexicanos en Manila, 1710-1815. UNAM, Mexico D.F.

Yuste López, Carmen (2013) "De la libre contratación a las restricciones de la permission. La andadura de los comerciantes de México en los giros iniciales con Manila, 1580-1610”. In Un océano de seda y plata. El universo económico del Galeón de Manila. EEHA/CSIC, Madrid: 85-106.

Zaragoza, Ramón María (1990) Old Manila. Oxford University Press, Singapore. 